IZA DP No. 10139

Informal Employment in China:

Trends, Patterns and Determinants of Entry

Zhe Liang

Simon Appleton

Lina Song

August 2016 


\title{
Informal Employment in China: Trends, Patterns and Determinants of Entry
}

\author{
Zhe Liang \\ Nottingham University Business School \\ Simon Appleton \\ University of Nottingham \\ and IZA \\ Lina Song \\ Nottingham University Business School \\ and IZA
}

\section{Discussion Paper No. 10139 \\ August 2016}

\author{
IZA \\ P.O. Box 7240 \\ 53072 Bonn \\ Germany \\ Phone: +49-228-3894-0 \\ Fax: +49-228-3894-180 \\ E-mail: iza@iza.org
}

\begin{abstract}
Any opinions expressed here are those of the author(s) and not those of IZA. Research published in this series may include views on policy, but the institute itself takes no institutional policy positions. The IZA research network is committed to the IZA Guiding Principles of Research Integrity.

The Institute for the Study of Labor (IZA) in Bonn is a local and virtual international research center and a place of communication between science, politics and business. IZA is an independent nonprofit organization supported by Deutsche Post Foundation. The center is associated with the University of Bonn and offers a stimulating research environment through its international network, workshops and conferences, data service, project support, research visits and doctoral program. IZA engages in (i) original and internationally competitive research in all fields of labor economics, (ii) development of policy concepts, and (iii) dissemination of research results and concepts to the interested public.
\end{abstract}

IZA Discussion Papers often represent preliminary work and are circulated to encourage discussion. Citation of such a paper should account for its provisional character. A revised version may be available directly from the author. 


\section{ABSTRACT \\ Informal Employment in China: Trends, Patterns and Determinants of Entry*}

We empirically deconstruct informal employment in China into private business owners and casual workers without job contracts. Survey data from 2007 and 2013 document a rise in informal employment to the point where it exceeds formal employment, potentially an unintended consequence of the 2008 New Labour Contract Law. Compared with formal employees and business owners, casual workers report the lowest monetary and subjective wellbeing although business owners work longer hours with less social protection. Descriptive statistics and multivariate modelling reveal formal employees tend to have more favoured characteristics, often being educated, male, healthy and able bodied. Casual workers are more likely to have the characteristics of vulnerable groups, so the growth of casual employment is particularly concerning. There are indications that running small business is not always a sign of vulnerability and it may provide job flexibility for those with dependents to care for.

JEL Classification: D03, J46, O15, P23, P36

Keywords: informal employment, determinants, human capital, China

Corresponding author:

Lina Song

Division of Industrial Economics and Finance

Nottingham University Business School

Jubilee Campus

Nottingham, NG8 1BB

United Kingdom

E-mail: Lina.song@nottingham.ac.uk 


\section{Introduction}

The marked rise in informal employment, globally and in China in particular, has drawn attention to an ambiguity in how informally should be conceived. On the one hand, the informal sector has long been characterised as a hub for the poor and the vulnerable. On the other hand, informal employment also includes business owners who are often skilled and risk-taking. One response to this is to distinguish between two kinds of informal employment: casual workers - those who either are employees in formal sector but without formal contracts or in casual employment in the informal sector. Appropriate employment regulation and social policy will require a good empirical understanding of the pay and welfare differences between these groups of workers, and what determines the kind of employment status which an individual can attain.

In this chapter, we provide a contextualised analysis of informal employment in China, focussing on the distinction between business owners and casual employment. We define those who have business assets (private firm owners or entrepreneurs) or have registered officially as individual business holders as business owners. Other workers who have no job contracts are classified as casual workers, regardless of whether they work in a formal enterprise or in the informal sector. Formal employment is defined by whether one has received a job contract for at least one year. Using micro data from nationally representative surveys from 2007 and 2013, we document the rise in informal employment and consider its implications for workers' wellbeing, by comparing remuneration and other welfare indicators. We describe the characteristics of workers in the three categories of employment states (formal, casual and business) before using multinomial logit models to estimate the determinants of employment status in the two survey years. By using a range of explanatory variables, we try to establish whether informal employment status largely reflects vulnerable workers being unsuccessful in the attaining formal employment or whether it may be an optimal choice for some, for example by providing job flexibility. 
The received wisdom of informal employment as a residual activity for the most vulnerable or unlucky workers originates from early studies of the labour markets of developing nations. Economists asserted that dual sectors existed in such economies; low-skilled or less competitive rural-urban migrants, who left the village but could not secure better-paid urban formal jobs, would stay in the urban sector and be engaged in the interior informal employment (Harris and Todaro, 1970). Based on simple theoretical assumptions supported by some limited empirical findings, this characterisation was extremely influential in shaping opinion about the informal economy in 1970s, with the ILO among others, identifying the growth of the informal sector as an adverse phenomenon for the poor in low-income developing countries. Within the informal sector, working conditions were said to be deprived, with long hours, low pay and little or no social protection provided. Informality was further associated with labour market failure and chronic poverty (ILO, 2016).

However, this traditional view has been challenged by recent research which found some evidence that more and more well off or highly skilled workers become willingly engaged in such the so-called informal sector in the more developed economies. The sector may also help disadvantaged workers to become more competitive by gaining experiences or accumulating human capital. The fast growth of international trade, involving both the global North and South, among other factors, has reduced the size of the manufacturing sector and created job-loss in the advanced economies. In line with this, technological progress has led to changes in the industrial structure and changed views on 'work'. In more developed countries, there is a rising number of workers in selfemployment, in part due to the shift of capital investment for manufacturing production from the North to South. Examining the impacts of such a structural change on the labour market, a large proportion of labour force in the US, UK and Germany preferred being self-employed (Blanchflower and Oswald, 1998). Empirical evidence shows a trend of voluntary switch from formal salaried jobs to self-employment in both developed and developing countries (see Maloney, 2004, for a comprehensive review). Small micro firms and self-employed 
individuals are encouraged by Western governments as ways to limit unemployment following the reduction in manufacturing jobs.

In developing countries, such as much of sub-Saharan Africa, disappointing rates of growth of formal employment have led governments to look more favourably on the informal sector as the destination of their growing urban populations. Some emerging economies like Peru have treated informal sector as "the other path" to resolve poverty and instability (De Soto, 2002). China, the largest emerging economy, has become a mixed economy in which informal employment has played an important role during its transition, particularly for the urban-rural migrants attracted to the cities. However, the Chinese government denies the phenomenon of informality, and hence relevant policies have not been made to target this type of employment. Empirical research is therefore needed in order to improve our understanding of informal employment in China.

The chapter is organised as follows. Section 2 explains the concept of informality in the Chinese context, focussing on how self-employment should be distinguished between business owners and casual employment. Section 3 discusses the data and methods. Section 4 describes the changing patterns of informal employment in China, focusing on survey data from 2007 and 2013. Section 5 provides an econometric analysis on the determinants of employment status, focusing on the two kinds of informal employment. Section 6 concludes.

\section{Contextualising informal employment in China}

The Chinese government has never officially accepted the existence of informality. Instead, its official statistics use self-employment as an employment category differentiated from 'the employed' and unemployed. In official sources, 'self-employment' covers those who are 'employed persons in private enterprises' and 'self-employed individuals'. The rural labour force is another main category of labour, not included in the urban labour market. This crude method of classifying the Chinese labour force causes difficulties in examining 
employment in China in detail and risks making policies on labour issues irrelevant to real world concerns.

According to the Chinese Statistics Yearbooks (NBS, various years), China's labour force is divided by the rural and urban sectors based on household registration status and by primary, secondary and tertiary sectors. For the urban labour force, ownership of employment is the indicator of division; unemployed and self-employed are only be recorded for those with urban household registration. Although rural-urban migrants total around 260 million, it is unclear whether they appear in the category of urban or rural labour force and whether their unemployment or self-employment is recorded in official statistics (Song, 2015).

To research on informality in China, we start with an empirical classification of employment status using nationally representative labour force surveys from 2007 and 2013. A more conceptual review of informal employment definitions can be found in Song, Appleton and Liang (2016). As discussed above, the Chinese labour force is officially defined by rural and urban sectors. We focus on the urban labour force, but include rural-urban migrants who work in urban areas. The surveys allow us to reclassify urban employment status into three: 1) salaried workers with contracts (formal employees hereafter); 2) wage workers who have no job contract in any ownership sector (casual workers hereafter). 3) Business owners and self-employed individuals with businesses (business owners hereafter).

The rationale for making this three-fold classification is to throw light on job security and with it social protection. We set having a job contract as the defining characteristic of formal employment because this is the most important indicator for welfare. The 2008 New Labour Contract Law (PRC, 2007) legally requires all employers to offer contracts and provide those who have over two-yearcontracts with social insurance. However, there are variation in implementation - the law is only legally binding with more established firms or entities, typically those in the formal sector. Furthermore, private business employers may well 
avoid such laws due to the lack of mechanisms to monitor compliance. Employers in service sectors (e.g. catering, domestic, and repair shops) typically do not offer contracts and social insurance payment to their employees. Further, self-employed individuals (especially low-skilled labourers) are neglected by the law. These workers are often in casual jobs that can be within establishments in the formal sector. To save employment costs, firms in the formal sector often hire temporary employees for short-term goals or hire low skilled manual labourers to do unskilled jobs without offering formal contracts (e.g. as cleaners, security guards, and low-level of office workers). While casual workers are often grouped together with business owners as being in the informal sector, in our analysis we regard business owners as a separate category. These business owners may be sole proprietors working alone, they may work in a household enterprise or they may run a business with fewer than seven employees.

\section{Data and methods}

The data we use are drawn from the household surveys known as Chinese Household Income Project (CHIP) collected and administrated by a team of international scholars (CHIP, 2016). The CHIP data are a series of crosssectional surveys. For this analysis, we use 2007 and 2013 surveys combining the samples of registered urban residents and of rural-urban migrants ${ }^{1}$. We focus on individuals in the labour force, defined as those aged from 16 years to 65 years who were neither in full-time education nor retired.

Two exercises are covered in this chapter. In the first exercise, we map out the changes by employment status between 2007 and 2013. The reason we select 2007 and 2013 for this research is largely due to an important policy event which took place during the period. In January 2008, China's New Labour Contract Law was launched and implemented. The law has become controversial

\footnotetext{
${ }^{1}$ Sampling weights are used to obtain representative results, see CHIP (2016) for details.
} 
ever since with the key concern that a rise in labour costs would reduce employment and FDI. We can thus use information from 2007 prior to the new law and then see how things had changed employment status after 6 years. However, attributing all changes to the law would be unwarranted as the time interval also covers the onset the global financial crisis in 2008.

In the second exercise, we estimate multinomial logistic models to establish the determinants of the employment status, distinguishing formal employees, casual workers and business owners. The main research questions are:

(1) To quantify the impacts of institutional classification on employment status of the Chinese labour force. Specifically, we look at the effect of household registration - whether hukou is in urban or rural - and of rural-urban migrant status.

(2) To test whether the more vulnerable - those lacking human capital, in poor health, disabled or women - are more likely to work in informal employment - either as casual workers or business owners.

(3) To examine whether flexible employment is an optimal choice for some who would have the young or elderly to care for.

Details of the model specification will be discussed in Section 5, but first we turn to describing the trends in employment status, their associations with the wellbeing of workers and the characteristics of workers in the three groups.

\section{Employment status and wellbeing}

Between 2007 and 2013, there has been a dramatic switch from formal to casual employment (Table 1). The proportion of formal employees dropped from $65 \%$ in 2007 to $43 \%$ in 2013, while proportion of casual workers increased from $24 \%$ to $42 \%$. The proportion of business owners rose from $11 \%$ to $15 \%$. As a result of these changes, the once dominant formal sector of PR China has been exceeded, 
in terms of employment, by the informal sector (combining casual workers and business owners).

\section{Differences in wellbeing by employment status}

What are the implications of this switch in employment status for the wellbeing of workers? Table 2 outlines the difference in monetary welfare indicators by employment type. The indicators imply that, at the mean, the most beneficial type of employment is formal employment, followed by being a business owner with casual workers being the most disadvantaged. This is true for hourly wages, household income per capita and net household assets per capita (excluding housing and business investment).

There are few further issues we should highlight from this table. There is substantial overall growth in terms of monetary welfare indicators. For example, mean household income per capita nearly doubled for the casual workers between 2007 and 2013 (calculated in 2007 prices). The hourly wage for these workers also increased the most - by $36 \%$ - compared to rises of $33 \%$ for formal employees and $26 \%$ for business owners. The faster income growth of casual workers narrowed the differentials between them and other types of workers. In 2007, the household income per capita of casual workers averaged just half of that of formal employees and was 34\% less than that earned by business households. By 2013, the gap had narrowed to 29\% less than formal employees and $23 \%$ less than business owners.

In addition to monetary welfare indicators, it is important to consider differences in social insurance between the types of employment (Table 3 refers). In 2007, the majority of formal employees were benefited from pensions, housing funds and insurance against a variety of risks - medical, unemployment and work-related injuries. By contrast, most casual employees and business owners only had medical insurance. Business owners had the lowest levels of social protection. Over the next six years, there was a major expansion in the coverage of both medical insurance and pensions for all 
workers, but particularly benefiting informal workers. By 2013, almost all (98\%) formal employees had medical insurance, but so did the vast majority of workers $(91 \%)$ in the informal sector due to the central initiatives to mobilise a required health insurance covering all rural registered households. Rural-urban migrants were automatically insured by this scheme (PRC, 2005) but with limited funds. Pension coverage of informal workers roughly doubled: from $37 \%$ of casual workers in 2007 to $72 \%$ in 2013; for business owners, the rise was from $29 \%$ to $66 \%$. There were increases in other forms of social insurance, but these were more modest.

Health is another important dimension of welfare and so it is interesting to see how it varies by type of employment (Table 4 refers). However, inferring causality from these correlations is difficult: although income, social insurance and work risks may affect health, health may itself affect employment status. For example, poor health or disability may lead to termination of formal employment ${ }^{2}$. The CHIP data measure health using self-reported assessments of global health status. Only around 2\% of workers report being in poor or very poor health, but these are disproportionately found in informal employment. Similarly, around 2\% of workers report being disabled and this is also more common in informal employment. There is evidence of a general improvement in worker health status over time (and a fall in disability). The proportion of workers reporting being in excellent health has increased substantially, particularly among - but not confined to - formal employees (where it rose from $25 \%$ to $40 \%)$.

Subjective wellbeing of workers also appears to have risen, although a note of caution is required as the original questionnaires of 2007 and 2013 used different scales for reporting happiness. We have simplified the scales to three categories to try to make them comparable: happy, indifferent and not happy. Formal employees and business owners both report being happier than casual

2 This is despite laws protecting the employment rights of disabled individuals passed since the 1980s. For example, firms can be awarded credits if they recruit a certain number of disabled employees. 
workers (see Table 5). In 2007, only $29 \%$ of casual workers are happy compared to $36 \%$ of formal workers and $35 \%$ of business owners. There are large increases in happiness across all groups by 2013, but the differentials remain.

\section{Descriptive statistics on worker characteristics and demographics}

Given the welfare differences associated with different employment status, it is interesting to examine what kind of workers are typically found in each category (Table 6 refers). The proportion of migrants among the workforce falls from $27 \%$ in 2007 to $20 \%$ in 2013. Migrants account for relatively few formal employees: $18 \%$ in 2007 , falling to $9 \%$. They make up more than two fifths of casual employment and self-employment in 2007 but this has fallen by 2013, particularly in casual employment. The lack of access of migrants to the benefits of formal employment can be largely attributed by China's labour policies over the past decades that rural-urban migrants are empirically found inferior to their urban counterparts in terms of job-seeking (Knight and Song, 1995, 2005), pay and labour market entry (Appleton et al, 2002; Long et al, 2014) and social protection (Song and Appleton, 2008).

It is conventional to regard informality as the refuge of more vulnerable workers in terms of age, sex and education (Table 7). However, this characterisation is simplistic, failing to distinguish between casual workers and business owners, and the patterns are changing over time. For example, casual workers were the youngest group in both years of our data, but the mean age gap fell over time. In 2007 , casual workers averaged 3 years younger than formal employees but by 2013 , they were only 1 year younger. Business owners are the oldest of the three groups of workers.

Women's participation in all three types of employment is lower than their male counterparts in both years. This has challenged the legacy of China's high female labour market participation, although it has been falling over recent decades, from 73\% in 1990 to 64\% in 2014 (World Bank, 2016). However, women are disproportionately concentrated in casual employment: in almost equal numbers 
of both sexes were casual workers (49\% were women, 51\% men), despite women constituting only $43 \%$ of the sample of workers. By 2013, the proportion of women in casual employment had fallen in 2013 (to 46\%). While the proportion of women in formal employment or business was smaller but remained the same (around $40 \%$ to $42 \%$ ) in the both years of data.

Education is a key indicator to measure human capital, the skills and knowledge of workers. Formal employees have the highest average years of education: 12.1 in 2007 rising to 12.8 in 2013. Casual workers and business owners have less around 10 years, with little change over time.

Family: structure of age group and marriage union or dissolution

Having young children or/and elderly in the family may affect one's employment status if one can choose. This is even more so in a country like China where care for the young and the old is typically neither commercialised nor accommodated by the public sector. When they move to work in the urban centres, rural-urban migrants have to decide whether to take those whom they have to care for with them, or leave them behind in villages. Even if care could be provided commercially in cities, affordability may be an issue. Casual work and business owners are likely to be more compatible with caring for family members. If this is so, household demographics may affect job selection (Table 8).

Of all three types of employment, business owners have the highest ratio of children to household size, while casual workers are the least likely (this goes both children aged 0-6 and those aged 7-12, and it holds true in both 2007 and 2013). Business owners also have the smallest proportion of working age household members in both years. The proportion of elderly in households rises over time, but particularly for business owners who go from having the smallest proportion of elderly in 2007 to the largest in 2013.

Marital status may also affect employment type, as being married may help to support a family business. It is theorised that marriage may permit an efficient 
labour division between couples, perhaps enabling one member to engage in household production (potentially including both domestic duties and a household economic enterprise) while another finds market work (Becker, 1972). By contrast, for casual workers, especially for rural-urban migrants, the pattern of "living apart together" has been commonly observed in China. Living arrangements for migrant couples often involve separation during the employment period. This arrangement does not allow them live their daily life together, and some of them dwell in different cities, or even in the same city, they may only be able to stay one or two weekends per month together (Lee, 2016). Couples living apart together are still financially responsible for the needs of their households including the cost of house-building and care for children and elders (Zhou and Zhou, 2013). The next section aims to establish whether marital status, among other variables, is a determinant of employment status.

\section{Determinants of employment status}

The descriptive statistics in Section 4 provide background information on how employment status is correlated with variables of interest. However, the results are bivariate, so it is no clear if, ceteris paribus, employment status is significantly related to a given factor on its own. In this section, we establish the determinants of employment status using multinomial logistic regression models estimated separately for 2007 and 2013. The dependent variable, $E_{i}$, is employment status: formal employees, casual workers and business owners. Formally, the model can be specified as:

$$
\operatorname{Pr}\left(E_{i}=k\right)=\frac{\exp ^{\beta_{k} X_{i}}}{1+\sum_{j=1}^{3} \exp ^{\beta_{j} X_{i}}} \quad k=1,2,3
$$

In this equation, the probability of individual i having an employment status $\mathrm{k}$ depends on a set of explanatory variables of $X_{i}$, each with a set of coefficients $\beta_{k}$. Among the explanatory variables, we use a dummy variable for having an urban hukou to test for whether institutional status determines type of employment. Also we controlled for the personal characteristics discussed in Section 4: age 
and sex, self-reported health status, physical ability (whether disabled), marital status and educational attainment. We also include a set of independent variables for household demographics to test whether employment status is affected by individuals' need for flexible employment. Industrial sector and regional dummy variables are also included as control variables.

The results of the multinomial logit are reported in Table 9 for the estimated probabilities, and Table 10 for marginal effects. For each explanatory variable, we present either a predicted probability, if the variable is qualitative, or a marginal effect, if the variable is continuous. Bootstrapping is used to calculate standard errors, as this provides consistent estimates if residuals are not normal. The number of observations for 2007 totals 10,232 and that for 2013 is 10,508. In terms of the goodness of fit, the pseudo $\mathrm{R}^{2}$ of the model for 2007 is 0.24 , and that for 2013 is 0.32 .

\section{Institutional determinant -the rural and urban divide?}

In both models, we control for registered urban residentship (hukou) as a proxy for institutional differences. Hukou status in China has long divided rural and urban populations. It is a paradox that Communist China, a state formed by peasant revolutionaries, has instituted a system of official household registration that discriminated against peasants. Until late last century, the hukou system was part of the administrative controls that effectively walled off the cities from those born in rural areas and helped create a marked rural-urban divide in living standards. By the 1990s, these controls started to be relaxed, enabling mass migration of rural workers into urban areas in search of higher incomes and dramatically contributing to poverty reduction in China. However, lacking urban hukou, rural-urban migrants remained second-class citizens, unable to access key urban government services (including schools and health clinics) or to compete for certain protected jobs (Song, 2015).

The results of multinomial logit are presented in two ways. The predicted probabilities of being in different employment states for workers with particular 
values of discrete explanatory variables. For example, residents with urban hukou are more likely to be engaged in formal employment (with at least one year job contract) than rural-urban migrants. Ceteris paribus, in 2007, an urban resident has a $66 \%$ probability of being a formal employee compared with $60 \%$ for migrants (a five point difference). In 2013, the figures fall to $45 \%$ for urban residents and 37\% for migrants (an 18 percentage point difference). Although the proportion of workers in formal employment decreased from 2007 to 2013, the decrease was larger - both absolutely and relatively - for migrants than urban residents. Thus institutional differences appear to have widened over the period.

The second way of presenting the results is Table 10, which records the marginal effects of each variable and whether they are statistically significant. For example, being a migrant (lacking an urban hukou) has a significant effect (at the $5 \%$ level) on the probability of formal employment and being a business owner in both years. However, in neither year was there a significant effect of being a migrant on the probability of being a casual worker. Instead, there is a striking difference in the probability of being a business owner. Migrants are more likely than urban residents to engage in such work and the difference in the predicted probabilities has been widened over time. In 2007, $14 \%$ of migrant workers are predicted to be engaged in business compared to $10 \%$ of urban workers. This has both increased to 20\% for migrants and 13\% for urban residents in 2013 .

\section{Capability or vulnerability}

Acquisition of capability symbolises one's employment status. Lacking it, an individual would be regarded as vulnerable in a competitive labour market. Our models of employment include several variables which may reflect capabilities notably educational attainment, a proxy for skills, and health plus disability status, indicators of physical abilities. Other personal characteristics such as age and gender may also be relevant, in so far as they are related to differences in productivity, preferences or discrimination. For example, previous research found that the sex and age of employees were key factors determining who was 
made redundant during the retrenchment of SOEs in the second half of the 1990s. Those who were retrenched were by and large older and female (Appleton et al, 2005).

Other things being equal, the models find being female increases the chances of being workers in casual employment and reduces the chances of them being business owners. Being a woman worker raises the probability of being in casual employment by $5 \%$ in 2007 and $4 \%$ in 2013. Correspondingly, it lowers the probability of being in the more rewarding category of business owners by around $4 \%$ in both years. Gender is statistically insignificant in affecting the probability of formal employment

The likelihood of workers being in particular kinds of employment varies with age, but the relationships are often non-monotonic as shown by the quadratic relations estimated in Table 9 and plotted in Figures 1 and 2 . The only monotonic relationship is the effect of age on the probability of formal employment in 2007, which is negative. This reflects a predicted switch out of formal employment into business owners and, after around age 30, casual employment. In 2013, the effect of age on formal employment takes an inverse U-shape, being highest at age 36 .

The probability of being a business owner rises with age until the worker is in their mid to late 40s (the turning point is 44 in 2007, rising to 48 in 2013). Age may be helpful to starting one's own business to the extent that it allows workers to have accumulated capital and expertise. One might speculate that the negative effect of age on self-employment in the 50 s and early $60 \mathrm{~s}$ is a consequence of the investment aspect of running one's own business. As workers head towards retirement, investing time and capital in an enterprise may appear less attractive due to shortening time horizon to reap returns.

By contrast, the effects of age on the probability of casual employment are initially negative and then turn positive. The negative effect of age for younger workers is particularly pronounced in 2013. For example, an increase in the age 
of a worker from 16 to 30 would reduce the probability of being in casual employment by 16 percentage points in 2013 compared to 3 points in 2007. This suggests that youth has become an increasingly important factor in determining whether workers are in casual employment. Younger workers may have been more subject to the general trend towards the casualization of employment in China because it may be easier for employers to offer new employees casual employment than to remove the protections enjoyed by existing workers. However, after a certain age (30 in 2007; 40 in 2013), age starts to increase the probability of casual employment. This absolute magnitude of this effect is similar in both surveys - for example, increasing age from 40 to 60 increases the probability of casual employment by 13-14 percentage points in both 2007and 2013.

Worker's age will partly reflect their accumulated general work experience. Time spent in their current job is also controlled for, as it may affect their specific job experience. Ceteris paribus, job tenure is positive associated with formal employment and negatively associated with casual employment. An extra year of tenure is predicted to raise the probability of formal employment by $1.4 \%$ in both 2007 and 2013. There are corresponding reductions in the probability of casual employment, albeit somewhat bigger in 2013 when tenure is also positively associated with being a business owner.

While work experience is sometimes interpreted as a measure of human capital, our main proxy for skills and knowledge is educational attainment. More years of education raise the probability of formal employment while lowering that of business owners and, especially, casual employment. The effects have become somewhat stronger over time. Ceteris paribus, every extra one-year of education would add 2.6 percentage points to the chance of formal employment in 2007, rising to 3.3 points in 2013. Conversely, every extra year of education would reduce probability of casual work by $1.7 \%$ in 2007 and by $2.3 \%$ in 2013 . For business owners, every extra year in education would reduce the probability by $1 \%$ of both years. Education therefore plays an increasing role in securing workers formal employment and avoiding casual employment in particular. 
A second aspect of human capital is the health of workers. While the significance of the relationships varies, the general pattern is that greater health is associated with formal employment and lower health is associated with casual employment. Specifically, health status does not significantly affect the probability of being in formal employment in 2007, but in 2013 , being in excellent health is associated with higher formal employment, ceteris paribus. Being in average health, rather than excellent health, increases the probability of being in casual employment by 4-5 percentage points in both years (the same is true for good health, relative to excellent health, in 2013). As noted in Section 4, interpreting these relationships is difficult because of the possibility of two-way causation. For example, it is not clear whether employers are selecting health workers for formal employment or whether casual employment carries health risks. The empirical relationship between health and the likelihood of being in informal employment is complex and changing. In 2013, running a business seems to resemble formal employment, in that lower health status has a negative marginal effect (relative to excellent health). In 2007, the relationships are non-monotonic: those in very poor or poor health are more likely to be business owners than those with excellent health; however, those in good or average health are less likely.

A more objective health indicator -disability - is included in the models. We find that compared with those not being disabled, being disabled increase the probability of being a business owner by two percentage points in 2007, increasing to five points in 2013. This suggests that the disabled sometimes be unable to find employment and so more likely to turn to self-employment, i.e., running one's own business.

\section{Optimal choices - seeking flexibility and happiness}

Flexible jobs, allowing one to juggle family and work life, can be something of luxury for workers, particularly in an emerging economy like China where much of the labour force is concentrated in manufacturing. As public or commercial services are lacking and not affordable, care for the young and old often relies 
heavily on family members. It is an interesting question, therefore, whether workers choose to be self-employment for the flexibility it provides or because they are unable to secure formal employment. The simple correlations reported in Section 4 between household demographics - specifically numbers of children - and the category of business owners suggests such a link; the models in Table 9 test whether than finding is robust to controls for other variables.

We measure household demographics by the proportions of household members in particular age groups. We find that in 2007, having more children (of all ages) significantly increases the likelihood of being a business owner and reduces the probability of being a casual worker. More children aged 7-12 years also has a negative effect on the probability of being in formal employment, in both 2007 and 2013. In 2013, most of these relationships are weaker and not statistically significant, although young children (0-6) do reduce the likelihood of being casual workers. These findings suggest that being casual workers may be more likely to choose running business if they have children, due to the flexibility it provides in terms of childcare. However, casual employment seems particularly unattractive to such workers: the work may be casual but it is not flexible. We also controlled for the proportions of elderly in the household but found mixed results, with no clear pattern. This may well reflect the Chinese character of care system for the elderly - a mixed of negligence, sharing among adult children's households, and possibly also institutionalised.

The finding that business owners were more likely to be married (Section 4 reports) is robust when other variables were controlled for. In 2007, being either divorced/widowed or being single both reduced the probability of being a business owner by 7 to 8 percentage points, while raising the probabilities of both formal and casual employment. In 2013, the effects were similar in sign but weaker and not always significant. The only significant effects were that divorce/widowed lowered the probability of being a business owner and raised that of being a casual worker. However, the models do not establish causality between informality (flexible and informal jobs) and the explanatory variables. Reverse causality remains a possibility: for example, having one's own business 
rather than being in casual employment may make one more likely to be married.

Similar caveats apply to the dummy variables entered into the model for subjective wellbeing. Controlling for other variables, lower levels of happiness tend to be associated with casual employment. The effect is significant for so-so level of happiness (relative to the default category of being happy or very happy) and even stronger for being not happy. The association between being not happy and casual employment becomes stronger in 2013 than in 2007. Not happy workers are less likely to be in formal employment (and, in 2007 only, business owners) ceteris paribus. This suggests a policy concern: the growing casualization of employment in China may lead to discontent among the workforce and so encourage instability.

\section{Sectoral changes between 2007 and 2013}

To estimate the determinants of employment type, we included dummy variables of 20 industrial sectors officially defined. Our intention is to estimate and compare the probabilities in order to outline the shifts between the two years. Some booming sectors in 2007 had downsized by 2013, and others may be up coming. However, to our surprise, the model predicted falls in the probability of formal employment between 2007 and 2013 in all 20 sectors, whether manufacturing, public service for others. The only difference was in the extent of the reduction. The highest reduction on formal employment are manufacturing, real estate, hotel and catering, wholesale and retail, and all sorts of public services (health and social security organisations; public management and social organisations; water conservancy and environment facilities; etc.), all of which saw reductions in probabilities of formal employment of more than 20 percentage points from 2007 to 2013. The smallest reduction on formal employment between the two years is from 'financial intermediation', which dropped from $69 \%$ in 2007 to $60 \%$ in 2013 . This seems to show that the financial sector fared better during 2007 and 2013. Adverse impacts of the global 
financial crisis starting from 2008 were not felt by China's financial sector until recently.

The probability of casual employment has experienced a large increase across the sectors. The sectors with the highest absolute increases were mining, manufacturing, IT, and public management and social organisation (all experiencing an increase of 20 percentage points or above). In fact, almost all the sectors have large increase of probabilities on casual work, showing that since 2007, fewer people received job contracts, and were employed with no contracts. This includes the export-oriented sectors including manufacturing and transport. This may partly a result of the slow-down of international trade from 2008. Manufacturing firms may have wished to downsize employment, or make it easier to downsize in future, and thus switched from formal sector to informal employment. In 2007, prior to the global finance crises, manufacturing workers had one of the highest predicted probabilities of being in formal employment of all the sectors but this fell to 53\% in 2013. The opposite trend was found for casual employment, which rose from $21 \%$ in 2007 is $43 \%$ in 2013.

\section{Conclusions}

In this research, we have looked at the growth of informal employment in China. Surveys from 2007 and 2013 record a dramatic rise in the proportion of urban workers in informal employment from $35 \%$ to $57 \%$, so that it now exceeds the proportion in formal employment. Our first main contribution is to empirically deconstruct informal employment into two types: business owners and casual workers (those without job contracts). Most of the rise in informal employment has taken the form of casual employment. This shift may reflect the change of labour policies since the launch of 2008 New Labour Contract Law. The heterogeneity of informal employment is illustrated by a comparison of welfare levels across different types of workers. Casual workers receive lower levels of remuneration and report lower subjective wellbeing than business owners, who in turn receive less than formal employees. However, business owners have the lowest levels of social protection and work the longest hours. There have been 
marked improvements in these welfare indicators between 2007 and 2013. However, the inequalities in welfare indicators between workers of different status echo Huang's (2013) concern that Chinese society is stratified between those with formal and informal jobs.

Our main focus has been on the characteristics of workers in different employment categories and modelling how these characteristics affect their employment status. We do find some evidence in favour of the conventional view that informal employment is a hub for the more vulnerable who are less able to compete. For example, education increases the probability of workers being formally employed, rather than that in casual jobs or running one's own business. Indeed, characteristics which make workers most likely to be formally employed are being educated, healthy, not disabled and male. For casual employment, one could add to this list both the young and the old. By 2013, being women, older and in poorer health are even more likely to land on casual employment. These findings have worrying implications for the impact of 2008 New Labour Contract Law, if only those who are more able can secure job contracts. It would be ironic if a Law designed to protect employees, in particular the poor and vulnerable, in fact saw vulnerable workers squeezed out into casual employment.

However, our research also suggests that informal employment is not always an activity of last resort and that business owners, in particular, are not always vulnerable or poor. Business owners are often prime aged workers, who have acquired useful work experience and perhaps savings. Running one's own business can provide benefits in terms of job flexibility to accommodate the need to take care of children or elderly relatives. When those in poor health and disability are rejected from jobs with formal contracts, running their own businesses may be an optimal choice. Thus, although there are concerns over the rise in casual employment, the increasing prevalence of workers running their own businesses may provide benefits for workers. 
In a brief summary, we empirically deconstruct informal employment in China into business owners and casual workers without job contracts. Survey data from 2007 and 2013 document a rise in informal employment to the point where it exceeds formal employment, potentially an unintended consequence of the 2008 New Labour Contract Law. Compared with formal employees and business owners, casual workers report the lowest monetary and subjective wellbeing although business owners work longer hours with less social protection. Descriptive statistics and multivariate modelling reveal formal employees tend to have more favoured characteristics, often being educated, male, healthy and able bodied. Casual workers are more likely to have the characteristics of vulnerable groups, so the growth of casual employment is particularly concerning. There are indications that running business is not always a sign of vulnerability and it may provide job flexibility for those with dependents to care for. 


\section{References}

Appleton, S., Knight, J., Song, L. and Xia, Q. (2002). “Labor retrenchment in China: Determinants and consequences", China Economic Review 13 (2-3), 252-275

Appleton S., Knight, J., Song, L. and Xia, Q. (2004). “Contrasting Paradigms: Segmentation and Competitiveness in the Formation of the Chinese Labour Market”. Journal of Chinese Economic and Business Studies, 2 (3), 185-206

Appleton, Simon, Song, Lina and Xia, Qingjie (2005). "Has China crossed the river? The evolution of wage structure in urban China during reform and retrenchment," Journal of Comparative Economics, Elsevier, 33(4), 644663.Becker, Garry (1993). A treaties on the family. Harvard University Press

Blanchflower, David G., and Andrew J. Oswald (1998). "What makes an entrepreneur?" Journal of labor Economics, 16 (1) 26-60.

CHIP (2016 forthcoming), Chinese Household Income Project.

De Soto, Hernando (2002). The other path: The economic answer to terrorism. Basic Books.

Harris, John R. \& Todaro, Michael P. (1970), "Migration, Unemployment and Development: A Two-Sector Analysis". American Economic Review, 60 (1): 126142.

Huang, Philip C. C. (黄宗智) (2013). “China’s Informal Economy Revisited” (中 国的非正规经济再论), Rural China, 10 (1), 66 -82, Koninklijke Brill NV, Leiden, The Netherlands

Lee, Jason (2016) "Migrant workers forced into long-distance marriages", www.China.org.cn

International Labour Organisation (ILO) (1993). Resolutions Concerning Statistics of Employment in the Informal Sector Adopted by the 15th International Conference of Labour Statisticians, ILO, Geneva.

International Labour Organisation (ILO) (2016), http://www.ilo.org/global/topics/employment-promotion/informal-economy/lang-en/index.htm

Long, Wenjin, Appleton, Simon and Song, Lina (2013). "Job Contact Networks and Wages of Rural-Urban Migrants in China," IZA Discussion Papers 7577, Institute for the Study of Labor (IZA).

Knight, J. and Song, L. (1999). The rural and urban divide: economic disparities and Interactions in China, Oxford University Press, Oxford 
Knight, J. and Song, L, (2005). Towards a labor market in China. Oxford University Press, Oxford

NBS, People's Republic of China: The Bureau of Statistics of PR China (various years) Chinese Statistic Yearbooks

Song, L. and Appleton, S. (2008). "Social protection and migration in China: what can protect migrants from economic uncertainty?" In: NIELSEN, I. and SMYTH, R., eds., Migration and social protection in China, World Scientific.

Song, L. (2015). “Why does hukou reform matter?”. A report prepared for Paulson Institute.

Song, Lina and Appleton, Simon and Liang, Zhe (2016). "Deconstructing Informality: A Response to Vulnerability or an Optimal Choice?". IZA Discussion Paper No. 10100. SSRN: http://ssrn.com/abstract=2819382

PR China (2005), State Council: [2005] No.1 Dossier.

PR China (2007) Labor Contract Law of the People's Republic of China Order of the President of the People's Republic of China (No. 65)

World Bank (2016) http://data.worldbank.org/indicator/SL.TLF.CACT.FE.ZS

Zhou, Jing and Zhou, Rui (2013). “Chinese Migrant Workers in 'Temporary Marriages'” All Women's Federation: August 29, 2013 
Table 1

Sample size and percentage by employment status (Unit is million for weighted sample)

\begin{tabular}{|c|c|c|c|c|c|c|c|c|}
\hline & \multicolumn{4}{|c|}{2007} & \multicolumn{4}{c|}{2013} \\
\hline Sample & $\begin{array}{c}\text { Formal } \\
\text { employee }\end{array}$ & $\begin{array}{c}\text { Casual } \\
\text { worker }\end{array}$ & $\begin{array}{c}\text { Business } \\
\text { owner }\end{array}$ & Total & $\begin{array}{c}\text { Formal } \\
\text { employee }\end{array}$ & $\begin{array}{c}\text { Casual } \\
\text { worker }\end{array}$ & $\begin{array}{c}\text { Business } \\
\text { owner }\end{array}$ & Total \\
\hline \multirow{2}{*}{ No weight } & 7,950 & 4,128 & 2,154 & 14,232 & 5,163 & 4,387 & 1,450 & 11,000 \\
\cline { 2 - 11 } & 55.86 & 29.01 & 15.13 & 100 & 46.94 & 39.88 & 13.18 & 100 \\
\hline \multirow{2}{*}{ With weight } & 154.2 & 56.38 & 25.39 & 236.0 & 157.6 & 153.67 & 53.40 & 364.69 \\
\cline { 2 - 10 } & 65.35 & 23.89 & 10.76 & 100 & 43.22 & 42.14 & 14.64 & 100 \\
\hline
\end{tabular}

Source: CHIP 2007, 2013

Table 2

Mean values of monetary welfare indicators by employment status Unit = RMB Yuan, hour

\begin{tabular}{|c|c|c|c|c|c|c|}
\hline & \multicolumn{3}{|c|}{2007} & \multicolumn{3}{c|}{2013} \\
\hline & $\begin{array}{c}\text { Formal } \\
\text { employee }\end{array}$ & $\begin{array}{c}\text { Casual } \\
\text { worker }\end{array}$ & $\begin{array}{c}\text { Business } \\
\text { owner }\end{array}$ & $\begin{array}{c}\text { Formal } \\
\text { employee }\end{array}$ & $\begin{array}{c}\text { Casual } \\
\text { worker }\end{array}$ & $\begin{array}{c}\text { Business } \\
\text { owner }\end{array}$ \\
\hline $\begin{array}{c}\text { Hourly wage } \\
\text { (2007 price) }\end{array}$ & 13.8 & 7.6 & 12.9 & 20.4 & 11.9 & 17.4 \\
\hline $\begin{array}{c}\text { Household income per } \\
\text { capita (2007 price) }\end{array}$ & 18705.5 & 9163.9 & 13811.3 & 25748.6 & 18166 & 23684 \\
\hline $\begin{array}{c}\text { Household asset per } \\
\text { capital } \\
(2007 \text { price) }\end{array}$ & 602.6 & 636.5 & 661.1 & 16795.9 & 10459.6 & 15203.1 \\
\hline Working hours per week & 44.66 & 52.28 & 66.91 & 48.83 & 53.85 & 61.83 \\
\hline
\end{tabular}

Source: CHIP 2007, 2013

Table 3

Social insurance coverage by employment status (\%)

\begin{tabular}{|c|c|c|c|c|c|c|c|c|}
\hline & \multicolumn{4}{|c|}{2007} & \multicolumn{4}{c|}{2013} \\
\hline & $\begin{array}{c}\text { Formal } \\
\text { employee }\end{array}$ & $\begin{array}{c}\text { Casual } \\
\text { worker }\end{array}$ & $\begin{array}{c}\text { Business } \\
\text { owner }\end{array}$ & Total & $\begin{array}{c}\text { Formal } \\
\text { employee }\end{array}$ & $\begin{array}{c}\text { Casual } \\
\text { worker }\end{array}$ & $\begin{array}{c}\text { Business } \\
\text { owner }\end{array}$ & $\begin{array}{c}\text { Total } \\
\text { Medical }\end{array}$ \\
90.43 & 71.77 & 67.92 & 84.15 & 98.22 & 90.95 & 90.73 & 94.06 \\
\hline Pension & 77.74 & 37.39 & 28.55 & 62.81 & 92.64 & 71.52 & 66.14 & 79.86 \\
\hline Unemployment & 60.66 & 16.40 & 9.61 & 44.60 & 59.76 & 19.29 & 7.51 & 35.09 \\
\hline $\begin{array}{c}\text { Work-related } \\
\text { injury }\end{array}$ & 55.87 & 16.04 & 7.23 & 41.13 & 59.08 & 19.91 & 7.10 & 34.99 \\
\hline Housing fund & 53.24 & 8.88 & 3.48 & 37.29 & 62.99 & 10.19 & 3.25 & 32.03 \\
\hline
\end{tabular}

Source: CHIP 2007, 2013 
Table 4

Health and disability distribution by employment status (\%)

\begin{tabular}{|c|c|c|c|c|c|c|c|c|}
\hline & \multicolumn{4}{|c|}{2007} & \multicolumn{4}{c|}{2013} \\
\hline & $\begin{array}{c}\text { Formal } \\
\text { employee }\end{array}$ & $\begin{array}{c}\text { Casual } \\
\text { worker }\end{array}$ & $\begin{array}{c}\text { Business } \\
\text { owner }\end{array}$ & Total & $\begin{array}{c}\text { Formal } \\
\text { employee }\end{array}$ & $\begin{array}{c}\text { Casual } \\
\text { worker }\end{array}$ & $\begin{array}{c}\text { Business } \\
\text { owner }\end{array}$ & $\begin{array}{c}\text { Total } \\
\text { Health: Excellent }\end{array}$ \\
\hline 24.75 & 26.44 & 28.75 & 25.59 & 39.57 & 33.02 & 36.89 & 36.42 \\
\hline Good & 54.75 & 48.58 & 50.00 & 52.76 & 45.89 & 49.14 & 46.63 & 47.37 \\
\hline Average & 19.02 & 22.71 & 18.49 & 19.85 & 13.40 & 15.56 & 14.32 & 14.45 \\
\hline Poor & 1.36 & 2.02 & 2.54 & 1.65 & 1.04 & 2.00 & 1.91 & 1.57 \\
\hline Very poor & 0.11 & 0.25 & 0.22 & 0.16 & 0.10 & 0.27 & 0.23 & 0.19 \\
\hline Disability: No & 98.07 & 97.40 & 96.89 & 97.78 & 98.56 & 98.46 & 98.21 & 98.47 \\
\hline $\begin{array}{c}\text { Yes but not } \\
\text { serious }\end{array}$ & 1.68 & 2.20 & 2.47 & 1.89 & 1.28 & 1.00 & 1.10 & 1.14 \\
\hline Seriously disabled & 0.25 & 0.39 & 0.64 & 0.33 & 0.16 & 0.54 & 0.69 & 0.40 \\
\hline
\end{tabular}

Source: CHIP 2007, 2013

Table 5

Happiness distribution by employment status (\%)

\begin{tabular}{|c|c|c|c|c|c|c|c|c|}
\hline & \multicolumn{4}{|c|}{2007} & \multicolumn{4}{c|}{2013} \\
\hline & $\begin{array}{c}\text { Formal } \\
\text { employee }\end{array}$ & $\begin{array}{c}\text { Casual } \\
\text { worker }\end{array}$ & $\begin{array}{c}\text { Business } \\
\text { owner }\end{array}$ & Total & $\begin{array}{c}\text { Formal } \\
\text { employee }\end{array}$ & $\begin{array}{c}\text { Casual } \\
\text { worker }\end{array}$ & $\begin{array}{c}\text { Business } \\
\text { owner }\end{array}$ & Total \\
\hline Happy & 35.79 & 28.54 & 34.87 & 33.86 & 70.83 & 53.88 & 67.59 & 63.28 \\
\hline Indifferent & 57.79 & 59.79 & 55.30 & 58.00 & 26.64 & 39.09 & 28.43 & 32.10 \\
\hline Not happy & 6.42 & 11.68 & 9.83 & 8.14 & 2.53 & 7.02 & 3.98 & 4.62 \\
\hline
\end{tabular}

Source: CHIP 2007, 2013

Table 6

Proportion of migrants and urban residents by employment status (\%)

\begin{tabular}{|c|c|c|c|c|c|c|c|c|}
\hline & \multicolumn{4}{|c|}{2007} & \multicolumn{4}{c|}{2013} \\
\hline & $\begin{array}{c}\text { Formal } \\
\text { employee }\end{array}$ & $\begin{array}{c}\text { Casual } \\
\text { worker }\end{array}$ & $\begin{array}{c}\text { Business } \\
\text { owner }\end{array}$ & Total & $\begin{array}{c}\text { Formal } \\
\text { employee }\end{array}$ & $\begin{array}{c}\text { Casual } \\
\text { worker }\end{array}$ & $\begin{array}{c}\text { Business } \\
\text { owner }\end{array}$ & Total \\
\hline Rural migrant & 17.87 & 43.36 & 44.85 & 26.88 & 8.6 & 26.94 & 35.09 & 20.12 \\
\hline Urban & 82.13 & 56.64 & 55.15 & 73.14 & 91.4 & 73.06 & 64.91 & 79.79 \\
\hline Total & 100 & 100 & 100 & 100 & 100 & 100 & 100 & 100 \\
\hline
\end{tabular}

Source: CHIP 2007, 2013 
Table 7

Personal characteristics: age, gender and education by employment status

\begin{tabular}{|c|c|c|c|c|c|c|c|c|}
\hline & \multicolumn{4}{|c|}{2007} & \multicolumn{4}{c|}{2013} \\
\hline & $\begin{array}{c}\text { Formal } \\
\text { employee }\end{array}$ & $\begin{array}{c}\text { Casual } \\
\text { worker }\end{array}$ & $\begin{array}{c}\text { Business } \\
\text { owner }\end{array}$ & Total & $\begin{array}{c}\text { Formal } \\
\text { employee }\end{array}$ & $\begin{array}{c}\text { Casual } \\
\text { worker }\end{array}$ & $\begin{array}{c}\text { Business } \\
\text { owner }\end{array}$ & $\begin{array}{c}\text { Total } \\
\text { Age (year) }\end{array}$ \\
\hline 38.2 & 35.8 & 38.4 & 37.67 & 40.6 & 39.2 & 42.2 & 40.24 \\
\hline $\begin{array}{c}\text { Gender (\%): } \\
\text { Female }\end{array}$ & 41.28 & 49.39 & 39.84 & 43.06 & 41.39 & 46.46 & 41.75 & 43.58 \\
\hline Male & 58.72 & 50.61 & 60.16 & 56.94 & 58.39 & 53.54 & 58.25 & 56.42 \\
\hline Total & 100 & 100 & 100 & 100 & 100 & 100 & 100 & 100 \\
\hline $\begin{array}{c}\text { Education } \\
\text { (year) }\end{array}$ & 12.1 & 10 & 9.5 & 11.35 & 12.8 & 10.2 & 9.6 & 11.22 \\
\hline
\end{tabular}

Source: CHIP 2007, 2013

Table 8

Household Characteristics: age ratio to household size and marital status by employment status (\%)

\begin{tabular}{|c|c|c|c|c|c|c|c|c|}
\hline & \multicolumn{9}{|c|}{2007} & \multicolumn{4}{c|}{2013} \\
\hline Age cohort: & $\begin{array}{c}\text { Formal } \\
\text { employee }\end{array}$ & $\begin{array}{c}\text { Casual } \\
\text { worker }\end{array}$ & $\begin{array}{c}\text { Business } \\
\text { owner }\end{array}$ & Total & $\begin{array}{c}\text { Formal } \\
\text { employee }\end{array}$ & $\begin{array}{c}\text { Casual } \\
\text { worker }\end{array}$ & $\begin{array}{c}\text { Business } \\
\text { owner }\end{array}$ & \begin{tabular}{c} 
Total \\
\hline $0-6$
\end{tabular} \\
4.63 & 3.15 & 6.37 & 4.46 & 4.85 & 4.51 & 5.63 & 4.82 \\
\hline $7-12$ & 4.56 & 3.37 & 6.31 & 4.47 & 5.67 & 5.50 & 7.60 & 5.88 \\
\hline $13-15$ & 2.23 & 1.79 & 2.88 & 2.20 & 3.12 & 2.99 & 3.19 & 3.07 \\
\hline $16-59$ & 83.30 & 86.55 & 81 & 83.83 & 80.5 & 79.62 & 75.87 & 79.45 \\
\hline $60-69$ & 3.29 & 3.45 & 2.47 & 3.24 & 3.91 & 5.31 & 5.81 & 4.78 \\
\hline $70-79$ & 1.50 & 1.34 & 0.63 & 1.37 & 1.39 & 1.49 & 1.36 & 1.43 \\
\hline $80-89$ & 0.38 & 0.29 & 0.27 & 0.35 & 0.48 & 0.49 & 0.31 & 0.46 \\
\hline$>=90$ & 0.10 & 0.03 & 0.05 & 0.08 & 0.04 & 0.07 & 0.16 & 0.07 \\
\hline $\begin{array}{c}\text { Marriage: } \\
\text { Married }\end{array}$ & 80.08 & 68.69 & 91.33 & 78.57 & 88.8 & 80.48 & 94.05 & 86.06 \\
\hline $\begin{array}{c}\text { Divorced/ } \\
\text { widowed }\end{array}$ & 2.28 & 3.12 & 1.46 & 2.39 & 2.06 & 3.72 & 2.32 & 2.80 \\
\hline Single & 17.65 & 28.19 & 7.21 & 19.04 & 9.14 & 15.8 & 3.63 & 11.14 \\
\hline Total & 100 & 100 & 100 & 100 & 100 & 100 & 100 & 100 \\
\hline
\end{tabular}

Source: CHIP 2007, 2013 
Table 9

Predicted probabilities of employment from multinomial logit models

\begin{tabular}{|c|c|c|c|c|c|c|}
\hline & \multicolumn{3}{|c|}{2007} & \multicolumn{3}{|c|}{2013} \\
\hline & $\begin{array}{c}\text { Formal } \\
\text { employee }\end{array}$ & $\begin{array}{l}\text { Casual } \\
\text { worker }\end{array}$ & $\begin{array}{c}\text { Business } \\
\text { owner }\end{array}$ & $\begin{array}{c}\text { Formal } \\
\text { employee }\end{array}$ & $\begin{array}{l}\text { Casual } \\
\text { worker }\end{array}$ & $\begin{array}{c}\text { Business } \\
\text { owner }\end{array}$ \\
\hline Urban (reference) & 0.659 & 0.241 & 0.0995 & 0.454 & 0.418 & 0.128 \\
\hline Migrant & 0.599 & 0.259 & 0.143 & 0.373 & 0.425 & 0.201 \\
\hline Gender: Male (reference) & 0.640 & 0.224 & 0.137 & 0.442 & 0.396 & 0.162 \\
\hline Female & 0.628 & 0.276 & 0.0964 & 0.436 & 0.438 & 0.126 \\
\hline $\begin{array}{l}\text { Marriage: Married } \\
\text { (reference) }\end{array}$ & 0.630 & 0.237 & 0.132 & 0.439 & 0.410 & 0.150 \\
\hline Divorced/widowed & 0.685 & 0.255 & 0.0604 & 0.417 & 0.462 & 0.121 \\
\hline Single & 0.658 & 0.288 & 0.0541 & 0.451 & 0.455 & 0.0937 \\
\hline $\begin{array}{l}\text { Health: Excellent } \\
\text { (reference) }\end{array}$ & 0.637 & 0.234 & 0.129 & 0.455 & 0.388 & 0.157 \\
\hline Good & 0.644 & 0.246 & 0.110 & 0.429 & 0.429 & 0.143 \\
\hline Average & 0.614 & 0.276 & 0.110 & 0.430 & 0.437 & 0.133 \\
\hline Poor & 0.585 & 0.266 & 0.149 & 0.425 & 0.457 & 0.118 \\
\hline Very poor & 0.579 & 0.185 & 0.236 & 0.328 & 0.644 & 0.0285 \\
\hline Disability: No (reference) & 0.635 & 0.249 & 0.115 & 0.439 & 0.416 & 0.144 \\
\hline Yes & 0.618 & 0.245 & 0.137 & 0.410 & 0.397 & 0.193 \\
\hline $\begin{array}{l}\text { Happiness: Happy } \\
\text { (reference) }\end{array}$ & 0.648 & 0.229 & 0.123 & 0.451 & 0.387 & 0.163 \\
\hline So-so & 0.637 & 0.252 & 0.111 & 0.425 & 0.454 & 0.121 \\
\hline Not happy & 0.569 & 0.302 & 0.129 & 0.371 & 0.516 & 0.113 \\
\hline $\begin{array}{l}\text { Industry: } \\
\text { Agriculture (reference) }\end{array}$ & 0.690 & 0.263 & 0.0474 & 0.277 & 0.397 & 0.326 \\
\hline Mining & 0.768 & 0.155 & 0.0770 & 0.645 & 0.331 & 0.0241 \\
\hline Manufacturing & 0.769 & 0.205 & 0.0264 & 0.527 & 0.430 & 0.0431 \\
\hline $\begin{array}{l}\text { Production and Supply of } \\
\text { Electricity, Gas and Water }\end{array}$ & 0.773 & 0.206 & 0.0209 & 0.596 & 0.378 & 0.0253 \\
\hline Construction Enterprise & 0.498 & 0.440 & 0.0619 & 0.336 & 0.592 & 0.0720 \\
\hline $\begin{array}{l}\text { Transport, Storage and Post } \\
\text { Industry }\end{array}$ & 0.690 & 0.240 & 0.0700 & 0.453 & 0.412 & 0.135 \\
\hline $\begin{array}{l}\text { Information Transmission, } \\
\text { Computer Services and } \\
\text { Software }\end{array}$ & 0.633 & 0.180 & 0.187 & 0.449 & 0.455 & 0.0956 \\
\hline Wholesale and Retail Trade & 0.435 & 0.250 & 0.315 & 0.232 & 0.370 & 0.398 \\
\hline Hotel and Catering Services & 0.533 & 0.303 & 0.164 & 0.257 & 0.495 & 0.248 \\
\hline Financial Intermediation & 0.689 & 0.298 & 0.0130 & 0.606 & 0.366 & 0.0280 \\
\hline Real Estate Industry & 0.734 & 0.245 & 0.0203 & 0.480 & 0.464 & 0.0566 \\
\hline $\begin{array}{l}\text { Leasing and Business } \\
\text { Services }\end{array}$ & 0.526 & 0.302 & 0.172 & 0.283 & 0.511 & 0.205 \\
\hline
\end{tabular}




\begin{tabular}{|l|r|r|r|r|r|r|}
\hline $\begin{array}{l}\text { Scientific Research, } \\
\text { Technical Service }\end{array}$ & 0.647 & 0.233 & 0.121 & 0.558 & 0.442 & $2.28 \mathrm{e}-12$ \\
\hline $\begin{array}{l}\text { Management of Water } \\
\text { Conservancy, Environment } \\
\text { and Public Facilities }\end{array}$ & 0.885 & 0.0805 & 0.0342 & 0.645 & 0.333 & 0.0215 \\
\hline $\begin{array}{l}\text { Services to Households and } \\
\text { Other Services }\end{array}$ & 0.617 & 0.275 & 0.107 & 0.326 & 0.499 & 0.175 \\
\hline Education & 0.773 & 0.202 & 0.0242 & 0.636 & 0.340 & 0.0247 \\
\hline $\begin{array}{l}\text { Culture, Sport and } \\
\text { Entertainment }\end{array}$ & 0.732 & 0.233 & 0.0358 & 0.545 & 0.421 & 0.0342 \\
\hline $\begin{array}{l}\text { Health, Social Security and } \\
\text { Social Welfare }\end{array}$ & 0.608 & 0.284 & 0.108 & 0.385 & 0.442 & 0.174 \\
\hline $\begin{array}{l}\text { Public Management and } \\
\text { Social Organization }\end{array}$ & 0.866 & 0.134 & $3.96 \mathrm{e}-13$ & 0.643 & 0.345 & 0.0114 \\
\hline International Organizations & 1.000 & $1.27 \mathrm{e}-12$ & $7.44 \mathrm{e}-13$ & 1.000 & $1.40 \mathrm{e}-10$ & $1.28 \mathrm{e}-11$ \\
\hline
\end{tabular}

Source: CHIP 2007, 2013 
Table 10

Multinomial logit models on determinants of employment status Presented in terms of marginal effects

\begin{tabular}{|c|c|c|c|c|c|c|}
\hline & \multicolumn{3}{|l|}{2007} & \multicolumn{3}{|l|}{2013} \\
\hline & $\begin{array}{l}\text { Formal } \\
\text { employee }\end{array}$ & $\begin{array}{l}\text { Casual } \\
\text { worker }\end{array}$ & $\begin{array}{l}\text { Business } \\
\text { owner }\end{array}$ & $\begin{array}{l}\text { Formal } \\
\text { employee }\end{array}$ & $\begin{array}{l}\text { Casual } \\
\text { worker }\end{array}$ & $\begin{array}{l}\text { Business } \\
\text { owner }\end{array}$ \\
\hline Migrant & $-0.061 * * *$ & 0.0176 & $0.043^{* * *}$ & $-0.080 * *$ & 0.007 & $0.074 * * *$ \\
\hline Age & 0.002 & $-0.010 * * *$ & $0.008 * * *$ & $0.016^{*}$ & $-0.027 * * *$ & 0.010 \\
\hline Age*age & -0.0001 & $0.0002^{* * *}$ & $-0.0001^{* * *}$ & $-0.0002 * *$ & $0.0003 * * *$ & -0.0001 \\
\hline Gender: Female & $-0.012 *$ & $0.052 * * *$ & $-0.040 * * *$ & -0.006 & $0.042 * * *$ & $-0.036 * * *$ \\
\hline Education in years & $0.026 * * *$ & $-0.017 * * *$ & $-0.009 * * *$ & $0.033 * * *$ & $-0.023 * * *$ & $-0.010 * * *$ \\
\hline $\begin{array}{l}\text { Year worked for } \\
\text { current job }\end{array}$ & $0.014 * * *$ & $-0.013 * * *$ & -0.0006 & $0.0138 * * *$ & $-0.017 * * *$ & $0.003 * * *$ \\
\hline Health: Good & 0.007 & $0.012^{*}$ & $-0.019 * * *$ & $-0.026 * * *$ & $0.040 * * *$ & -0.014 \\
\hline Average & $-0.022 *$ & $0.042 * * *$ & $-0.020 * * *$ & $-0.025 * * *$ & $0.049 * * *$ & $-0.023^{*}$ \\
\hline Poor & $-0.052 *$ & 0.032 & $0.019 * * *$ & -0.030 & 0.069 & $-0.039 * * *$ \\
\hline Very poor & -0.058 & -0.049 & $0.107 * * *$ & -0.126 & 0.255 & -0.129 \\
\hline Disability: Yes & -0.017 & -0.004 & $0.021^{* * *}$ & -0.029 & -0.020 & $0.048 * *$ \\
\hline Family age ratio: $0-6$ & -0.035 & $-0.111^{* * *}$ & $0.146 * * *$ & 0.022 & $-0.110 * * *$ & 0.088 \\
\hline $7-12$ & $-0.085 * * *$ & $-0.052 * * *$ & $0.137 * * *$ & $-0.092 * * *$ & 0.014 & 0.078 \\
\hline $13-15$ & -0.030 & $-0.053^{* * *}$ & $0.083 * * *$ & 0.018 & -0.022 & 0.004 \\
\hline $60-69$ & 0.010 & -0.029 & 0.018 & -0.066 & $0.038 * * *$ & 0.028 \\
\hline $70-79$ & $-0.085 * *$ & $0.327 * * *$ & $-0.242 * * *$ & -0.101 & 0.081 & 0.021 \\
\hline 80-89 & 0.104 & $-0.298 * * *$ & $0.194 * * *$ & -0.097 & 0.186 & -0.089 \\
\hline \multicolumn{7}{|l|}{ Marriage: } \\
\hline Divorced/widowed & $0.055^{* * *}$ & $0.018^{* *}$ & $-0.072 * * *$ & -0.023 & $0.051^{* * *}$ & $-0.029 * *$ \\
\hline Single & $0.027 * * *$ & $0.051^{* * *}$ & $-0.078 * * *$ & 0.012 & 0.045 & -0.057 \\
\hline Happiness: Indifferent & $-0.011 * * *$ & $0.023 * * *$ & $-0.013 * * *$ & $-0.026 * *$ & $0.067 * * *$ & $-0.042 * * *$ \\
\hline Not happy & $-0.079 * * *$ & $0.073 * * *$ & 0.006 & $-0.079 * * *$ & $0.129 * * *$ & $-0.050 * * *$ \\
\hline \multicolumn{7}{|l|}{ Industry: } \\
\hline 1.Mining & 0.078 & $-0.108^{*}$ & 0.030 & $0.367 * * *$ & -0.065 & $-0.302 * * *$ \\
\hline 2.Manufacturing & $0.079 * * *$ & $-0.058 *$ & $-0.021 * * *$ & $0.249 * * *$ & 0.034 & $-0.283 * * *$ \\
\hline $\begin{array}{l}\text { 3.Production and } \\
\text { Supply of Electricity, } \\
\text { Gas and Water }\end{array}$ & $0.083^{*}$ & -0.057 & $-0.027^{*}$ & $0.318^{* * *}$ & -0.017 & $-0.301 * * *$ \\
\hline $\begin{array}{l}\text { 4.Construction } \\
\text { Enterprise }\end{array}$ & $-0.191 * * *$ & $0.177 * * *$ & $0.014 * *$ & 0.059* & $0.195 * * *$ & $-0.254 * * *$ \\
\hline $\begin{array}{l}\text { 5. Transport, Storage } \\
\text { and Post Industry }\end{array}$ & 0.0002 & -0.023 & $0.023 * *$ & $0.175^{* * *}$ & 0.016 & $-0.191 * * *$ \\
\hline 6.Information & -0.057 & $-0.083^{* *}$ & $0.140 * * *$ & $0.172 * * *$ & $0.059 * * *$ & $-0.231^{* * *}$ \\
\hline $\begin{array}{l}\text { Transmission, } \\
\text { Computer Services and } \\
\text { Software Industry }\end{array}$ & & & & & & \\
\hline $\begin{array}{l}\text { 7.Wholesale and Retail } \\
\text { Trade }\end{array}$ & $-0.255^{* * *}$ & -0.012 & $0.267 * * *$ & -0.045 & -0.027 & $0.072 * *$ \\
\hline $\begin{array}{l}\text { 8.Hotel and Catering } \\
\text { Services }\end{array}$ & $-0.156 * * *$ & 0.040 & $0.116^{* * *}$ & -0.020 & $0.098 * *$ & $-0.079 *$ \\
\hline $\begin{array}{l}\text { 9.Financial } \\
\text { Intermediation }\end{array}$ & -0.0004 & 0.035 & $-0.034 * * *$ & 0.328 & -0.030 & $-0.298 * * *$ \\
\hline 10.Real Estate Industry & 0.044 & -0.017 & $-0.027 * *$ & 0.202 & 0.068 & -0.270 \\
\hline $\begin{array}{l}\text { 11.Leasing and } \\
\text { Business Services }\end{array}$ & $-0.164 * * *$ & 0.040 & $0.124^{* * *}$ & 0.007 & $0.115^{* * *}$ & $-0.121^{* *}$ \\
\hline $\begin{array}{l}\text { 12.Scientific Research, } \\
\text { Technical Service }\end{array}$ & -0.043 & -0.030 & $0.073 * * *$ & $0.281^{* * *}$ & 0.046 & $-0.326 * * *$ \\
\hline $\begin{array}{l}\text { 13.Management of } \\
\text { Water Conservancy, } \\
\text { Environment and }\end{array}$ & $0.196^{* * *}$ & $-0.183 * * *$ & -0.013 & $0.367 * * *$ & -0.062 & $-0.305 * * *$ \\
\hline
\end{tabular}


Public Facilities

14. Services to
15. Education
16. Health, Social
Security and Social
Welfare

$-0.060 *$

$-0.023 * * *$

$0.357 * * *$

$0.267 * * *$

$-0.056$

17. Culture, Sport and

Entertainment

18. Public

0.022

$0.060 * * *$

$0.107^{* * *}$

$0.045^{* *}$

$-0.152 * * *$

Management and

$0.176^{* * *}$

$-0.129 * * *$

$-0.047^{* * *}$

$0.365^{* * *}$

$-0.050$

$-0.315^{* * *}$

Social Organization

Observations

10232

10508

Pseudo R ${ }^{2}$

\section{Notes:}

(1) The table presents marginal effects for all variables.

(2) * denotes $\mathrm{p}<.1$, ** $\mathrm{p}<.05$, *** $\mathrm{p}<.01$

(3) The omitted variables are urban residents, male, excellent health, no disability, aged 16-59, married, happy, agriculture sector.

(4) In both models, we controlled for province dummy variables. For brevity, the results are not presented here.

(5) Bootstraps are employed for calculating standard errors.

Source: CHIP 2007, 2013 
Figure 1: Marginal effect of Age on Probability of Employment, 2007

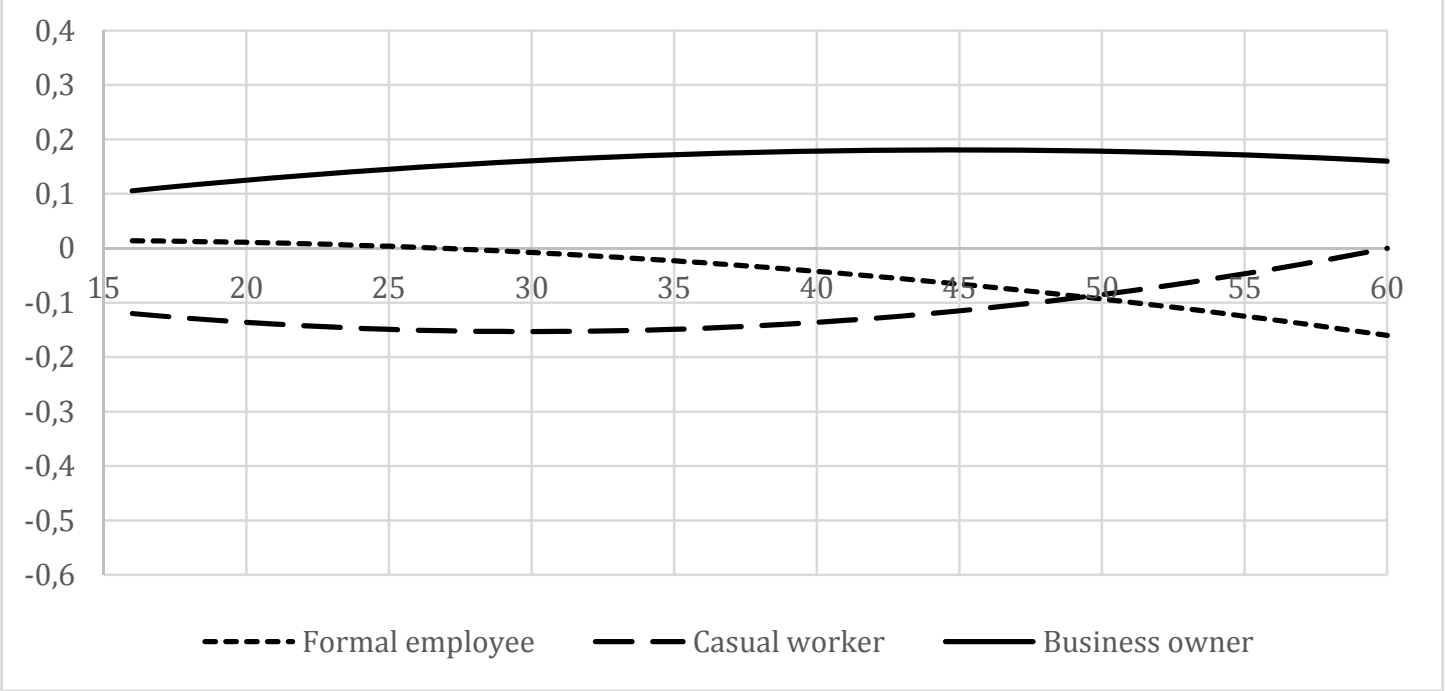

Figure 2: Marginal effect of Age on Probablility of Employment, 2013

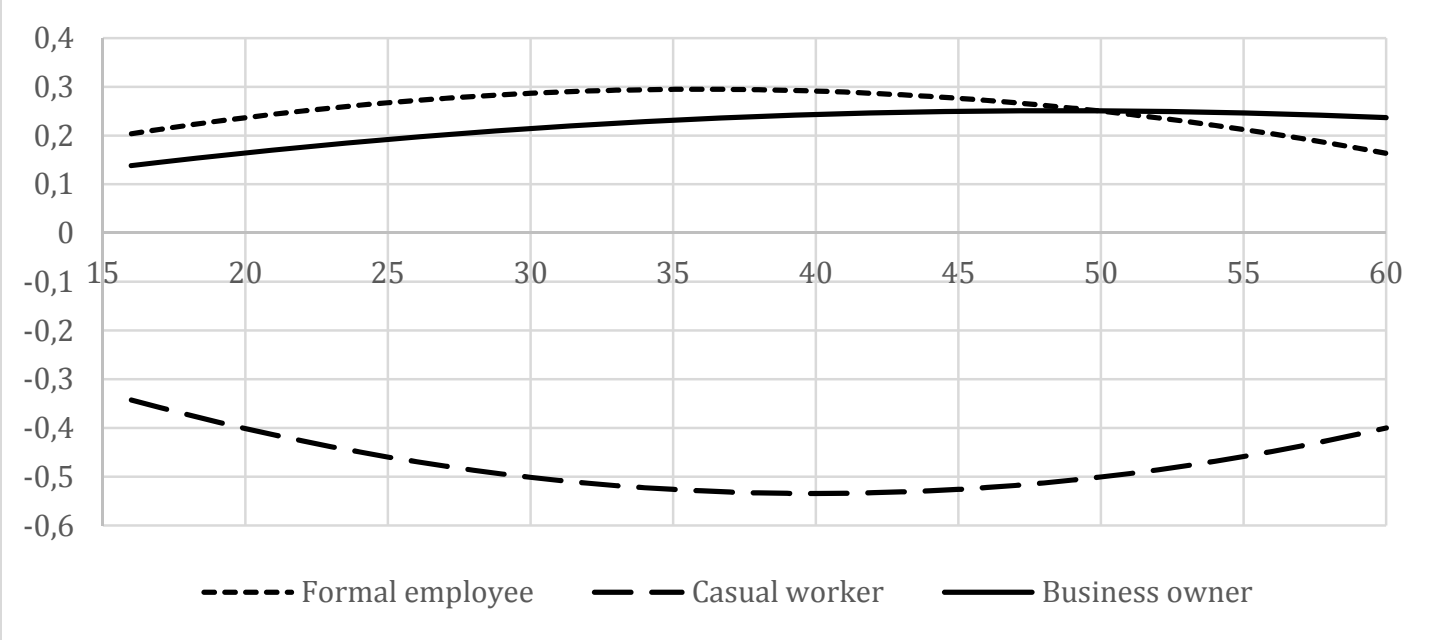

